ISSN 0258-7122

Bangladesh J. Agril. Res. 40(2): 229-233, June 2015

\title{
EFFICACY OF FUNGICIDES TO CONTROL STEMPHYLIUM BLIGHT (STEMPHYLIUM BOTRYOSUM) OF LENTIL
}

\author{
M. SHAHIDUZZAMAN ${ }^{1}$, M. ABUL HOSSAIN ${ }^{2}$, N. D. KUNDU ${ }^{3}$
}

\begin{abstract}
A field experiment was carried out during Rabi seasons of 2011-12 and 2012-13 to evaluate the efficacy of fungicides in controlling Stemphylium blight ( $S$. botryosum) of lentil. Five fungicides were evaluated under higher disease pressure $\left(10^{6} \mathrm{ml}^{-1}\right)$ of Stemphylium blight. Results revealed that Foliar spray (4 sequences) with Rovral 50WP (Iprodione) @ (0.2\%) and Secure 600WG (Fenamidione+Mancozeb) @ (0.2\%) at an interval of 7 days effectively controlled the disease and increased yield of lentil by $31.99 \%$ and $28.20 \%$, respectively. The fungicides may be selected for control of the disease.
\end{abstract}

Keywords: Efficacy, Stemphylium Blight, Fungicide, Lentil.

\section{Introduction}

Lentil (Lens culinaris Medik) is the second most important pulse crop in terms of both area and production (Anon., 2014). The crop is vulnerable to many diseases. At least 15 pathogens causing 17 diseases of lentil have been recorded in Bangladesh (Ahmed, 1986). Among the diseases, Stemphylium blight (S. botryosum Wallroth) is a major one in Bangladesh (Bakr and Zahid, 1986). Generally, it appears at flowering stage of the crop. Relatively high temperature (around $21^{\circ} \mathrm{C}$ ) and high humidity (90\%) enhance the disease development. Control of plant diseases becomes successful and economical when management approach contains several methods including chemical means (Bakr and Ahmed, 1992), cultural practices (Howlider et al., 1989, Rahman et al., 1988) and use of resistant varieties (Ahmed, 1986). Use of fungicide is the most dependable method to control plant diseases. Therefore, the present experiment was conducted to test five fungicides to control Stemphylium blight of lentil.

\section{Materials and Method}

The fungicides tested in the present experiment were Rovral 50WP (Iprodione), Secure 600 WG (Fenamidione+Mancozeb), Companion, Indofil-45 (Mancozeb) and Nativo 75WG (Tebuconazole+Trifloxystobin). All fungicides were applied as foliar spray at $0.2 \%$ suspension in plain water. The experiment was laid out in randomized complete block design with three replications. The unit plot size was $3 \mathrm{~m} \times 4 \mathrm{~m}$. Seeds of lentil variety BARI Masur-1 susceptible to Stemphylium blight were sown in continuous rows maintaining of $30 \mathrm{~cm} \times 5 \mathrm{~cm}$ row to row

${ }^{1}$ Scientific Officer, ${ }^{2}$ Chief Scientific Officer Regional Pulses Research Station, BARI, Madaripur, ${ }^{3}$ Scientific Officer, RARS, Rahmatpur, Barisal. 
spacing on 23 November, 2011 and 19 November, 2012. Intercultural operations were done whenever necessary. The experiment was visited regularly to observe the onset of the disease. Spraying of fungicides was started when the disease appeared on the crop. Four sprays were applied on 8, 15, 22 and 27 January, 2012 and 3, 10, 17 and 24 January, 2013. Data on severity of Stemphylium blight disease were recorded on 18, 25 and 30 January in 2012 and 13, 20 and 27 January in 2013. The disease severity was indexed on a 0-10 disease scoring scale (Hashemi et al., 2005) where, $0=$ Healthy plant; free of disease, $1=$ Dull leaves or few tiny tan spots, $2=$ A few small to large chlorotic spots, $3=$ Expanding lesions on leaves and leaf drop starting, $4=20 \%$ nodes on main stem showing chlorotic/necrotic symptoms and/or leaf drop, $5=40 \%$ nodes on main stem showing chlorotic/necrotic symptoms and/or leaf drop, $6=60 \%$ nodes on main stem showing chlorotic/necrotic symptoms and/or leaf drop, $7=80 \%$ nodes on main and lateral stems showing chlorotic/necrotic symptoms and leaf drop, $8=$ $100 \%$ leaves dried up/defoliated but small green tip recovering, $9=100 \%$ leaves dried up/defoliated including tip but stem still green, and $10=$ Whole plant die and completely dried up. The crops were harvested at full matured stage. Data on yield and other characters were recorded from 10 randomly selected plants in each plot. The crop was harvested on 9-13 March in 2012 and 8-10 March in 2013. Grain yield were determined based on the whole plot and expressed in kilogram per hectare. The recorded data were analyzed statistically. Means of treatments were compared following Least Significance Difference (LSD) test.

\section{Results and Discussion}

In 2011-2012 crop season, ranges in severity of Stemphylium blight, plant height, number of pod per plant and yield were 2.16-3.83, 24.33-30.87 cm, 25.27-33.13 and $673.30-986.90 \mathrm{~kg} / \mathrm{ha}$, respectively under various treatments including control. The highest disease severity was recorded from control. Treatments with different fungicides reduced disease severity by $8.62-43.60 \%$. The lowest reduction was obtained with Nativo followed by Companion and Indofil. The disease severity under Indofil and Secure was $26.11 \%$. The maximum and significant reduction was achieved with only Rovral compared to control. The lowest plant height of $24.33 \mathrm{~cm}$ was recorded from control and the treatment with Companion, which was statistically similar to the plant height observed under Indofil. Two fungicides, Secure and Nativo gave the maximum plant height of $30.87 \mathrm{~cm}$, which was statistically similar to the plant height recorded from Rovral treatment but significantly higher compared to other fungicides and the control. The lowest pod number was found under control which was statistically similar to the pod number recorded from Indofil and Companion. Other fungicides increased pod number significantly over control. The highest pod number was achieved with Secure followed by Nativo and Rovral. Effect of latter three fungicides on pod number was statistically similar. The lowest yield of lentil 
grain was recorded from control. All treatments with fungicides increased the yield significantly over control. The highest increase was achieved with Secure followed by Rovral and Nativo. The effect of three fungicides on yield was significantly different (Table 1).

Table 1. Efficacy of fungicides in controlling Stemphylium blight (S. botryosum) of lentil during rabi, 2011-2012 at RPRS, Madaripur

\begin{tabular}{l|c|c|c|c}
\hline Fungicides with concentration & $\begin{array}{c}\text { Stemphylium } \\
\text { blight severity } \\
(\mathbf{0 - 1 0} \text { scale) }\end{array}$ & $\begin{array}{c}\text { Plant height } \\
(\mathbf{c m})\end{array}$ & $\begin{array}{c}\text { No. of } \\
\text { pod } \\
\text { /plant }\end{array}$ & $\begin{array}{c}\text { Yield } \\
(\mathbf{k g} / \mathbf{h a})\end{array}$ \\
\hline Rovral 50WP(Iprodione) 2\% & $\begin{array}{l}2.16 \mathrm{~b} \\
43.60)\end{array}$ & $28.20 \mathrm{abc}$ & $30.27 \mathrm{ab}$ & $\begin{array}{c}986.90 \mathrm{~b} \\
(31.77)\end{array}$ \\
Secure 600WG & $2.83 \mathrm{ab}$ & $30.87 \mathrm{a}$ & $33.13 \mathrm{a}$ & $1083.00 \mathrm{a}$ \\
(Fenmidione+Mancozeb) 2\% & $(26.11)$ & & & $(37.83)$ \\
Companion 2\% & $3.16 \mathrm{ab}$ & $24.33 \mathrm{~d}$ & $27.47 \mathrm{~b}$ & $823.30 \mathrm{~cd}$ \\
& $(17.49)$ & & & $(18.21)$ \\
Indofil-45 (Mancozeb) 2\% & $2.83 \mathrm{ab}$ & $26.33 \mathrm{~cd}$ & $26.00 \mathrm{~b}$ & $750.00 \mathrm{~d}$ \\
& $(26.11)$ & & & $(11.40)$ \\
Nativo 75WG & $3.50 \mathrm{a}$ & & & $885.00 \mathrm{c}$ \\
(Tebuconazole+Trifloxystobin) 2\% & $(8.62)$ & $30.87 \mathrm{a}$ & $30.47 \mathrm{ab}$ & $(23.92)$ \\
Control (Plain water) & $3.83 \mathrm{a}$ & $24.33 \mathrm{~d}$ & $25.27 \mathrm{~b}$ & $673.30 \mathrm{e}$ \\
\hline
\end{tabular}

Values within a column having a common letter(s) do not differ significantly ( $\mathrm{P}=0.05)$.

Values within the parentheses are percent decrease of disease over control and percent increase of yield over control.

During 2012-2013 lentil growing season, ranges in severity of Stemphylium blight, plant height, number of pod per plant and yield ranged 2.00-4.16, 22.84$28.17 \mathrm{~cm}, 26.04-40.06$ and $968.00-1428.00 \mathrm{~kg} / \mathrm{ha}$, respectively under various treatments including control. The highest severity of Stemphylium blight was found under control, which was statistically similar to the treatments with Nativo and Companion. Other fungicides significantly reduce disease severity over control. The highest reduction was obtained with Rovral followed by Secure as well as Indofil. All fungicides increased plant height and pod yield per plant compared to control. However, significant increase in these parameters was achieved with only Nativo, Secure and Rovral. Effectiveness of three fungicides on plant height and pod number was statistically similar (Table 2). 
Table 2. Efficacy of fungicides in controlling Stemphylium blight ( $S$. botryosum) of lentil during rabi, 2012-2013 at RPRS, Madaripur.

\begin{tabular}{|c|c|c|c|c|}
\hline Fungicides with concentration & $\begin{array}{c}\text { Stemphylium } \\
\text { Blight severity } \\
\text { (0-10 scale) }\end{array}$ & $\begin{array}{c}\text { Plant } \\
\text { height } \\
\text { (cm) }\end{array}$ & $\begin{array}{c}\text { No. of } \\
\text { pods/plant }\end{array}$ & $\begin{array}{c}\text { Yield } \\
\text { (kg/ha) }\end{array}$ \\
\hline Rovral 50WP(Iprodione) $2 \%$ & $\begin{array}{l}2.00 \mathrm{~d} \\
(51.92)\end{array}$ & $28.17 \mathrm{a}$ & $40.06 \mathrm{a}$ & $\begin{array}{c}1428.00 \mathrm{a} \\
(32.21)\end{array}$ \\
\hline $\begin{array}{l}\text { Secure } 600 \mathrm{WG} \\
\text { (Fenmidione+Mancozeb) } 2 \%\end{array}$ & $\begin{array}{c}3.00 \mathrm{~d} \\
(27.88)\end{array}$ & $26.21 \mathrm{~b}$ & $33.02 \mathrm{ac}$ & $\begin{array}{l}1189.00 \mathrm{~b} \\
(18.58)\end{array}$ \\
\hline Companion $2 \%$ & $\begin{array}{l}4.00 \mathrm{a} \\
(3.85)\end{array}$ & $25.34 \mathrm{ab}$ & $31.55 \mathrm{bc}$ & $\begin{array}{l}1097.00 \mathrm{bc} \\
(11.75)\end{array}$ \\
\hline Indofil-45 (Mancozeb) 2\% & $\begin{array}{l}3.00 \mathrm{~b} \\
(27.88)\end{array}$ & $27.45 \mathrm{a}$ & $35.09 \mathrm{ab}$ & $\begin{array}{l}1254.00 \mathrm{ab} \\
(22.71)\end{array}$ \\
\hline $\begin{array}{l}\text { Nativo } 75 \mathrm{WG} \\
\text { (Tebuconazole+Trifloxystobin) } 2 \%\end{array}$ & $\begin{array}{c}3.83 \mathrm{ab} \\
(7.93)\end{array}$ & $28.13 \mathrm{a}$ & $38.88 \mathrm{ab}$ & $\begin{array}{l}1259.00 \mathrm{ab} \\
(23.11)\end{array}$ \\
\hline Control (Plain water) & $4.16 \mathrm{a}$ & $22.84 \mathrm{~b}$ & $26.04 \mathrm{c}$ & $968.00 \mathrm{c}$ \\
\hline
\end{tabular}

Values within a column having a common letter(s) do not differ significantly ( $\mathrm{P}=0.05)$.

Values within the parentheses are percent decrease of disease and percent increase of yield over control.

Results of the present investigation revealed that foliar spray with $0.20 \%$ suspension of all the tested fungicides reduced the disease severity and increased plant growth parameters and yield of lentil compared to control. Among five fungicides, Rovral, Indofil and Nativo showed better performance than other three in both test seasons. Similar findings had been recorded by many researchers. Bakr and Ahmed (1992) reported that disease score was the lowest whereas yield was the highest in plots treated with Rovral 50WP @ 0.2\%. Sardar (2005) also reported that the lowest disease severity was obtained from the Rovral 50WP and Tilt 250EC treated plots. So, the findings of the present investigation are comparable with the findings of the previous researchers.

\section{Conclusion}

Based on findings of the present study, it may be concluded that four times foliar spray with Rovral 50WP (Iprodione) or Secure 600WG (Fenamidione + Mancozeb) at an interval of 7 days may be recommended to control of Stemphylium blight of lentil. 


\section{References}

Ahmed, H.U. 1986. Recommendation in the methods of disease management of crop in Bangladesh. Plant Pathology Division. Bangladesh Agricultural Research Institute, Joydebpur Gazipur. Pp. 11-12

Anonymous, 2014. Acrage and Production of Pulse Crops, Agricultural Information Service, Krishi Diary, Department of Agricultural Extension, Bangladesh. P-14

Bakr, M. A. and M. I. Zahid. 1986. Stemphylium blight, a new foliar disease of lentil in Bangladesh. Bangladesh J. Plant Pathol. 2(1): 69-70.

Bakr, M.A. and F. Ahmed. 1992. Development of Stemphylium blight of lentil and it's control. Bangladesh J. Plant Pathol. 8(1\&2):39-40.

Hashemi, P., A. Vandenberg and S. Banniza. 2005. Developing a protocol for large scale inoculation of lentil germplasms with Stemphylium botryosum (Wallroth). In: Proceedings of Plant Canada 2005. Edmonton, AB, June 15-18. (Abstract)

Howlider, M.A.R, M.B. Meah, K. Anzuman-Ara, M. Bagum and A. Rahman. 1989. Effect of date of sowing on pod blight severity and yield of mustard. Bangladesh $\mathrm{J}$. Plant Pathol. 5(1\&2) : 41-46.

Rahman, M. L., H. U.Ahmed and I. H. Mian. 1988. Efficacy of fungicides in controlling purple leaf blotch of onion. Bangladesh J. Plant Pathol. 4(1\&2): 71-76.

Sardar, M. M. 2005. Chemical control of Stemphylium botryosum of lentil. M. Sc Thesis. Bangladesh Agricultural University. Mymensingh, Bangladesh. 